\title{
Risk Factors Associated with the Lameness in Crossbred Dairy Cattle Maintained Under Field Conditions
}

\author{
Rohit Kumar ${ }^{1}$, Mukund A. Kataktalware ${ }^{2 *}$, S. Senani ${ }^{3}$, M. Sivaram², Letha Devi G. ${ }^{3}$, \\ L. Niketha ${ }^{3}$ and K.P. Ramesha ${ }^{2}$ \\ ${ }^{1}$ ICAR-National Dairy Research Institute, Karnal, INDIA \\ ${ }^{2}$ Southern Regional Station, ICAR-National Dairy Research Institute, Bengaluru, INDIA \\ ${ }^{3}$ ICAR-National Institute of Animal Nutrition and Physiology, Bengaluru, INDIA \\ *Corresponding author: MA Kataktalware; E-mail: mtalware@gmail.com
}

Received: 27 Feb., 2021

Revised: 06 May, 2021

Accepted: 12 May, 2021

\begin{abstract}
A cross-sectional study was conducted with the objective to identify various risk factors associated with lameness in crossbred dairy cattle under unorganized production system in the state of Karnataka, India during November 2017 - May 2018. A total of 204 crossbred dairy cattle were investigated for lameness. The overall incidence of lameness was found to be $13.2 \%$. The Holstein Friesian crossbred dairy cows (18.2\%) were more prone to lameness than Jersey crossbred dairy cows (5.2\%) The age of the animals greater than 6 years (36\%), parity greater than three $(21.4 \%)$, body condition score less than three (19\%), animals affected with hoof disorders (35.5\%), animals having white-colored hooves (41.2\%), shallow foot angle (19.0\%), injured hocks and knees (48.3\% and $21.6 \%$ respectively) and animals maintained under unhygienic conditions $(22.9 \%)$ were significant risk groups for higher incidence of lameness. Among herd management level risk factors animals kept on dirty floors (17.5\%), freestall housing $(46 \%)$ and cemented floors $(44.8 \%)$ had a significantly higher incidence of lameness. Results of binary logistic regression model (sensitivity $93.01 \%$, specificity $77.8 \%$ and accuracy $97.67 \%$ ) revealed a significant set of risk factors and also provided adjusted odd ratios. The results showed that hoof disorders $(\mathrm{OR}=16.98 ; \mathrm{CI}=4.67-61.66)$, hock injury $(\mathrm{OR}=11.99$; $\mathrm{CI}=3.243-44.337)$ and lower body condition score $(\mathrm{OR}=6.99 ; \mathrm{CI}=1.72-28.37)$ were the significant predictors of lameness.
\end{abstract}

\section{HIGHLIGHTS}

(0 HF crossbred dairy cattle are more prone to lameness than Jersey crossbred.

0 Herd level factors like dirty floors, free-stall housing conditions and cemented floors also had significant association with lameness.

Keywords: Crossbred dairy cattle, Lameness, Risk factors

Lameness in dairy cattle is reflected by an alteration in their gait from normal to abnormal due to pain and discomfort caused by hoof or leg injury and disease (Flower and Weary, 2009). Lameness is known to have a negative impact on productivity as well as the reproductive performance of dairy cattle (Tyagi et al., 2017) and represents the serious concern about animal welfare (Whay and Shearer, 2017). It also leads to heavy economic losses to the dairy industry worldwide due to early culling, increased treatment cost and reduced milk yield (Green et al., 2014; Thomas et al., 2016). Previous studies have shown that farmers often fails in early detection of lameness (Rutherford et al., 2009) and many times they underestimate its occurrence and only presents the severe cases of lameness for treatment (Horseman et al., 2014). This indicates that efficient lameness prediction can have

How to cite this article: Kumar, R., Kataktalware, M.A., Senani, S., Sivaram, M., Letha Devi, G., Niketha, L. and Ramesha, K.P. (2021). Risk factors associated with the lameness in crossbred dairy cattle maintained under field conditions. J. Anim. Res., 11(3): 517-525.

Source of Support: None; Conflict of Interest: None

(c) 9 
a serious impact on its management. There are different management practices among different farms, regions and housing system and they influence the incidence and risk factors associated with lameness. Several studies reported that there are various risk factors which are associated with the lameness under organized farm conditions. However, there are scanty reports on risk factors associated under unorganized production system. Therefore, the present study was conducted to identify the risk factors associated with lameness in crossbred dairy cattle maintained under unorganized production system.

\section{MATERIALS AND METHODS}

The synopsis of this study was approved by the "Committee for the Purpose of Control and Supervision of Experiments on Animals" (CPCSEA) and Institutional Animal Ethics Committee (CPCSEA/IAEC/LA/SRSICAR-NDRI-2017/NO. 20).

The present study was conducted in Doddaballapura Taluk $\left(13.292^{\circ} \mathrm{N} 77.543^{\circ} \mathrm{E}\right)$ of Bengaluru Rural District, located in south-eastern part of Karnataka, India during November 2017 - May 2018. The average temperature and humidity of the study area were $25^{\circ} \mathrm{C}$ (range: 22 to $29^{\circ} \mathrm{C}$ ) and $61.25 \%$ (range: 49 to $75 \%$ ) respectively during the study period. The number of animals reared by the farmers in the study area was two to five mature cows along with their progenies per smallholder unit. The mature animals were investigated in each household once during the study period to determine the risk factors associated with the incidence of lameness. The data were collected directly from farmers using a questionnaire.

Data collected using questionnaire included information on animal level and herd management level factors. Animal level observations included were breed, age, parity, lameness, body condition score (BCS), hoof disorders, hoof colouration, foot angle, hock injury, knee injury and animal hygiene score. Herd management level observations included were feeding and watering practices, the housing condition (tie-stall or free-stall), type of flooring (stone slab, cemented and kachha (earthen) and floor cleanliness score. A total of 204 crossbred dairy cattle comprising 127 Holstein Friesian (HF) crossbred and 77 Jersey crossbred dairy cattle were investigated during the study period regardless of their lactation status.

\section{Lameness assessment}

A five-point scale of 1-5 developed by Sprecher et al. (1997) was used for measuring the lameness. Animals having scores 1 and 2 were assigned as clinically normal animals and animal having scores $\geq 3$ were considered as clinically lame. Lameness assessment was done early in the morning after milking on a flat surface.

\section{Body condition score}

A five-point scale of 1-5 was used for scoring (Ferguson et al., 1994). The measurements were done when the animal was feeding.

\section{Hoof disorders assessment}

For hoof inspection, animals were properly restrained and hooves were cleaned and debris was removed for a better and clear picture of disorders after proper restraining using International Claw Health Atlas (Egger-Danner et al., 2015).

\section{Hoof colouration}

It was assessed visibly during hoof examination and right hind foot was taken as standard in all the animals as suggested by Sogstad et al. (2011) because cleaning all the hooves of animal thoroughly by removing dirt and debris under field conditions is time-consuming and may increase discomfort in animal which can compromise animal cooperation during examination.

\section{Foot angle score}

It was assessed by using a scoring card given by the American Angus Association (foot score guidelines).

\section{Hock injury}

It was assessed using a 4 point ordinal scale with $0-3$ scoring where hocks with 0 and 1 scores were considered clinically normal hocks and 2 and 3 scores were considered clinically injured hocks (Gibbons et al., 2012).

\section{Knee injury}

It was assessed using a 4 point ordinal scale with $0-3$ 
scoring where knees with 0 and 1 scores were considered clinically normal knees and 2 and 3 scores were considered clinically injured knees (Gibbons et al., 2012).

\section{Floor cleanliness score}

It was assessed using boot test method which is used for assessment of floor cleanliness in dairy farms (Animal Comfort Tool, 2011). The scoring was done on a 4 point scale with $0-3$ scoring where 0 score was considered clean, 1 score was considered as a bit dirty, 2 score was considered as dirty and 3 score was considered as very dirty. Observations from score 0 and 1 were considered as clean whereas score 2 and 3 were considered as dirty.

\section{Animal hygiene score}

It was assessed by using a four-point scale with 1-4 scoring where 1 and 2 scores were considered clean and animal having score 3 and 4 considered dirty (Schreiner and Ruegg, 2003).

\section{STATISTICAL ANALYSIS}

Chi-square test of independence was used to test the association between risk factors and the incidence of lameness. Binary logistic regression analysis was employed to find out the significant predictive risk factors of lameness and to determine adjusted odds ratio (OR) with $95 \%$ confidence interval for the subgroups of risk factors (Hosmer and Lemeshow, 2000). $P$ values less than or equal to 0.05 was considered to be statistically significant. All the statistical analyses were done using IBM-SPSS Software 20.0.

\section{RESULTS AND DISCUSSION}

All the statistically significant results are presented in Table 1. The overall incidence of lameness was found at $13.2 \%$. The Holstein Friesian (HF) crossbred (18.1\%) genetic group had significantly $(\mathrm{p}<0.01)$ higher incidence of lameness than Jersey crossbred dairy cattle (5.2\%). This higher incidence in Holstein Friesian (HF) crossbred animals can be attributed to their selection for their high milk production trait which itself make them vulnerable to various production and reproduction related diseases and lameness is one out of them. Lohith et al. (2016b) also found a higher incidence of lameness in graded HF cattle followed by HF crossbred and Jersey crossbred respectively. Similarly, Bran et al. (2018) had also found that a higher incidence of lameness is associated with Holstein breed of cattle followed by crossbred dairy cattle and Jersey cattle respectively. Age of the cows had a significant effect on the incidence of lameness $(p<0.01)$. It was found that as the age of the cows advanced greater than six years, they were found to have more incidence of lameness $(36.0 \%)$ followed by cows under the age group less than $4-6$ years $(10.1 \%)$ and $<4$ years $(10 \%)$. Findings of the present study are in agreement with a study conducted by Dembele et al. (2006) who found that as age advanced, the incidence of lameness increased and followed an inverted "U" shaped relationship with age and highest risk for cows becoming lame were in age 7-8 years. However, results of the present study are not comparable with the study conducted by Rowlands et al. (1985) where they found that the vulnerability of cows to lameness increased four folds for cows over 10 years of age. The reason behind this may be that, in the present study, there were only a few numbers of animals above 10 years of age. Cows having parity greater than three had significantly $(\mathrm{p}<0.01)$ higher incidence of lameness $(21.4 \%)$ than those having parity $\leq 3(7.5 \%)$. These results are in agreement with the previous reports that as the parity increases the chances of a cow becoming lame also increase (Solano et al., 2016).

However, Sadiq et al. (2017) had not found any significant association between parity and lameness. Tyagi et al. (2017) reported the highest incidence of lameness in cows having $1^{\text {st }}$ parity and lower incidence were found in cows having $2^{\text {nd }}, 3^{\text {rd, }} 4^{\text {th }}$ and $5^{\text {th }}$ parity respectively. Reason behind this can be that these studies were conducted in organized farm conditions where low producing animals or aged animals were culled periodically due to their reduced production potential, whereas the present study was carried out under field conditions where smallholder dairy farmers are not following rigorous culling due to economic reasons which might be the reason that in the present study the incidence of lameness was higher in cows having parity greater than three. Cows having body condition score lower than three had significantly $(\mathrm{p}<0.01)$ higher incidence $(19.0 \%)$ compared to cows having a body condition score $\geq 3(5.7 \%)$. Present study revealed that the animal having a lower body condition score $(<3)$ were more prone to 
Table 1: The overall distribution of categorical (\%) animal- and herd-level variables for crossbred cows with lameness

\begin{tabular}{|c|c|c|c|c|}
\hline \multicolumn{2}{|l|}{ Variables } & \multirow{2}{*}{$\begin{array}{l}\text { Percentage of lame animals } \\
18.1\end{array}$} & \multirow{2}{*}{$\begin{array}{l}\text { Chi-square value } \\
6.963^{\mathrm{a}}\end{array}$} & \multirow{2}{*}{$\frac{\text { P- value }}{0.006}$} \\
\hline Genetic group & HF crossbred & & & \\
\hline & Jersey crossbred & 5.2 & & \\
\hline \multirow[t]{3}{*}{ Age } & $<4$ year & 10.0 & $12.858^{\mathrm{a}}$ & 0.002 \\
\hline & 4-6 year & 10.1 & & \\
\hline & $>6$ years & 36.0 & & \\
\hline \multirow[t]{2}{*}{ Parity } & $\leq 3$ & 7.5 & $8.384^{\mathrm{a}}$ & 0.004 \\
\hline & $>3$ & 21.4 & & \\
\hline \multirow[t]{2}{*}{ Body condition score } & $<3$ & 19.0 & $7.689^{\mathrm{a}}$ & 0.004 \\
\hline & $\geq 3$ & 5.7 & & \\
\hline \multirow[t]{2}{*}{ Hoof disorders } & Normal & 3.5 & $38.394^{\mathrm{a}}$ & 0.001 \\
\hline & Affected & 35.5 & & \\
\hline \multirow[t]{3}{*}{ Hoof coloration } & Black & 9.4 & $12.947^{\mathrm{a}}$ & 0.002 \\
\hline & White & 41.2 & & \\
\hline & Mixed & 12.3 & & \\
\hline \multirow[t]{2}{*}{ Foot angle score } & Intermediate & 9.21 & $4.201^{\mathrm{a}}$ & 0.034 \\
\hline & Shallow & 19.0 & & \\
\hline \multirow[t]{2}{*}{ Hock injury score } & Healthy & 7.4 & $36.14^{\mathrm{a}}$ & 0.001 \\
\hline & Injured & 48.3 & & \\
\hline \multirow[t]{2}{*}{ Knee injury score } & Healthy & 10.5 & $4.112^{\mathrm{a}}$ & 0.041 \\
\hline & Injured & 21.6 & & \\
\hline \multirow[t]{2}{*}{ Animal hygiene score } & Clean & 8.2 & $8.591^{\mathrm{a}}$ & 0.004 \\
\hline & Dirty & 22.9 & & \\
\hline \multirow[t]{2}{*}{ Floor cleanliness score } & Clean & 6.4 & $5.123^{\mathrm{a}}$ & 0.017 \\
\hline & Dirty & 17.5 & & \\
\hline \multirow[t]{2}{*}{ Type of housing } & Tie stall & 7.5 & $34.232^{\mathrm{a}}$ & 0.001 \\
\hline & Free stall & 46.7 & & \\
\hline \multirow[t]{3}{*}{ Type of floor } & Kachha & 0.0 & $29.668^{\mathrm{a}}$ & 0.001 \\
\hline & Stone slab & 8.2 & & \\
\hline & Cemented & 44.8 & & \\
\hline
\end{tabular}

lameness and this variable was also found as a significant predictor of lameness in final logistic regression model, which indicates that cows with lower BCS $(<3)$ are more likely to become lame and the findings are in agreement with previous studies who found strong association between low BCS and lameness in cattle (Randall et al., 2015; Lim et al., 2015; Singh et al., 2018; Sharma and Phillips, 2019) as BCS affect the thickness and quality of digital cushion (Bicalho et al., 2009). Dippel et al. (2009) found that cows having BCS greater than 3.5 had 0.39 lower odds of being lame. Sadiq et al. (2017) found no significant association between lameness and BCS. The difference might be due to the system of BCS used. Hoof examination of the cows revealed that the cows which were affected with the hoof disorders had significantly $(p<0.01)$ higher incidence of lameness $(35.5 \%)$ compared to cows with healthy hooves $(3.5 \%)$. In the present study, it was also observed that $81.48 \%$ of lame cows suffered from at least one hoof disorder and maximum no. of hoof disorder per lame cow was two and the percentage of those cows was $14.8 \%$. Similarly, Sadiq et al. (2017) found that $87.5 \%$ of the lame animals suffered from claw lesions and Moreira et al. (2018) found that hoof lesions were present in all the cows having lameness.

In the present study, the hoof disorders were found as a significant predictor for lameness in the final logistic 
regression model, which indicates that cows with hoof disorders are more likely to become clinically lame. Hoof colour was found to have a significant effect $(p<0.01)$ on the incidence of lameness. It was observed that animal with white coloured hooves had a higher incidence of lameness $(41.2 \%)$ followed by mixed coloured $(12.31 \%)$ and black coloured hooves $(9.4 \%)$.

In present study lighter coloured claws were found to suffer more with lameness compared to mixed and darker coloured claws respectively and the present finding is in agreement with Chesterton et al. (1989) who revealed that less pigmented hooves (more common in Friesian cattle) were more prone to lameness compared to the darker coloured hooves. He also found that Jersey cattle tend to have harder foot and was less prone to lameness. In the present study, $83.58 \%$ of Jersey crossbred cows had black hooves compared to $39.37 \%$ of HF crossbred cows. The stronger hooves may be the reason behind the lower incidence of lameness in Jersey crossbred cows. Similarly, it was also observed by Sogstad et al. (2011) that the cows with lighter colour claws were more likely to suffer from certain claw lesions like sole haemorrhages and white line disease compared to darker claws and similarly the cows with mixed coloured hooves were more likely to suffer from sole haemorrhages and corkscrew claws compared to darker claws. In this study, the author reported no significant associations of other claw disorders with claw horn colour. It suggests that the composition of the darker claws is much harder than the light coloured claws. Cows having shallow foot angle had significantly $(p<0.05)$ higher incidence $(19.0 \%)$ in comparison to those cows having intermediate foot angle (9.21\%). Lohith et al. (2016a) in crossbred cattle reported a higher incidence of hoof lesions in cows having intermediate foot angle followed by very steep and in very low foot angle. The reason behind variation with respect to the findings of the present study might be due to less number of observations in a very low foot angle and evaluation of animals for clinical lameness in the present study whereas

Lohith et al. (2016a) have associated this factor with the incidence of hoof disorders and they did not scored the cows for lameness. Cows with injured hock condition had significantly $(\mathrm{p}<0.01)$ higher incidence of lameness (48.3\%) compared to cows having normal hock condition $(10.5 \%)$. Similarly, cows with injured knees also had significantly $(p<0.05)$ more incidence of lameness
$(21.6 \%)$ compared to those with normal knees (10.5\%). In the present study, hock injury was found as a significant predictor of lameness in crossbred dairy cattle. Cows with injured hocks had more lameness compared to cows having clinically normal hock conditions and it is in agreement with previous reports which states that hock lesions are associated with an increased risk of lameness (Brenninkmeyer et al., 2012; Nash et al., 2016; Sadiq et al., 2017; Sharma and Phillips, 2019). Hock injuries are associated with hard abrasive flooring (Nash et al., 2016; Mostafa and Maharan, 2016). In the present study also the majority of animals were kept on hard flooring (stone slabs and cemented flooring). Similarly, cows with injured knees also had more lameness compared to cows had clinically normal knee conditions.

Our results are in agreement with previous studies (Mostafa and Maharan, 2016; Sharma and Phillips, 2019). Mostafa and Maharan, (2016) reported that concrete flooring in barns was a predisposing factor for injured knees in both tie-stall and free-stall systems where they observed a higher incidence of knee injury in both tie-stall and freestall barns. This can be attributed to the hardness of the stone slabs and cemented floors and the involvement of forelimbs which occurs first whenever animal rises and sit and can be the reason behind significant association among lameness and knee injury in the present study. Type of flooring was also found to have a significant $(p<0.01)$ effect on the incidence of lameness. Results in the present study revealed that Cows kept on cemented floors had a higher incidence of lameness $(44.8 \%)$ followed by cows kept on stone slabs $(8.2 \%)$ and the incidence of lameness was nil in animals kept on kachha floors.

These results are in agreement with previous studies which reports that concrete flooring is associated with lameness (Nash et al., 2016; Mostafa and Maharan, 2016). Concrete flooring causes excessive and uneven wear of hooves which leads to more skin breaks and increases chances of infections and also increases impact forces which predispose increased damage to corium (Fayed, 1997). Concrete flooring does not provide sufficient friction thus causing poor traction in floors and poor hoof grip with the ground (Van Der Tol et al., 2006). Therefore, grooving of floors is also recommended for maximizing traction in floors and to minimize wear and damage in hooves. Stone slabs have more roughened surface which may have better friction and provide better grip and traction, however, 
there is the risk of wear and skin breaks due to its hardness and uneven surface. This better grip and traction to hooves can be the reason behind fewer incidences in case of stone slabs flooring compared to cemented floors. Bovine hooves are well adapted to kachha floors because earthen floors provide better comfort to hooves due to its consistency and due to this there was no case of lameness observed under this category of flooring. Cows with dirty hygienic scores had significantly $(\mathrm{P}<0.01)$ higher incidence of lameness $(22.9 \%)$ compared to those with clean hygienic scores $(8.2 \%)$. Under herd-level risk factors, cows under dirty flooring conditions had significantly $(\mathrm{p}<0.05)$ higher incidence of lameness (17.5\%) compared to clean flooring condition (6.4\%). In the present study, cows with lower hygienic scores had a higher incidence of lameness in comparison to cows with clean hygienic condition which is in agreement with the findings of previous studies (Kara et al., 2011; Relun et al., 2013; Sadiq et al., 2017) that cows with dirty body conditions and very dirty leg hygienic conditions had increased risk of being lame.

Recently, Sharma and Phillips (2019) have also found a significant association between dirty udder conditions and lameness prevalence in 54 shelters (Gaushalas) in India. This dirtiness of the cows could be associated with the dirty flooring conditions in the farms and it is also found in the present study that dirty floor conditions had a significant influence on lameness. It was reported previously that exposure of cattle hooves to manure slurry on the floor and dirty leg conditions increases the claw conformational changes leading to lameness and also had a deleterious effect on claw health (Relun et al., 2013).

In a recent study done in Zimbabwe revealed that the cow cleanliness was found to be significantly $(p<0.001)$ associated with manure accumulation in cattle enclosures and was found to be significantly $(\mathrm{p}<0.001)$ associated with lameness also (Matore et al., 2018). This indicates that the dirty flooring and dirty animal hygienic conditions supplement the deterioration of claw health and increase the lameness. Cows kept under free-stall housing conditions had significantly $(\mathrm{p}<0.01)$ higher incidence of lameness $(46.7 \%)$ compared to cows who were kept on tie-stall housing conditions $(7.5 \%)$. These results are in agreement with several previous studies which reports that cows reared under free-stall housing had higher incidence of lameness compared to tie-stall housing (Cook, 2003;
Phillips and Morris, 2001). However, in contrary to the present study, Kara et al. (2011) reported that locomotion score in cows which were housed in free-stall was significantly lower than tie-stall on concrete bedding. The difference in findings may be due to different flooring material being used in the present study i.e. stone slab flooring in tie-stall houses and cemented flooring in free-stall houses in the study area. This indicates that the stone slabs flooring has less harmful effect on hooves in comparison to cemented flooring.

A final binary logistic regression model was developed had $91.67 \%$ accuracy, $93.01 \%$ sensitivity and $77.8 \%$ of specificity (Table 2). The model showed a reasonably good fit. Hoof disorders, BCS, parity, animal hygiene, hock injury and foot angle were six final explanatory variables present in the model (Table 2).

Table 2: Sensitivity, specificity and accuracy of the final binary logistic regression model

Classification Table ${ }^{\mathrm{a}}$

\begin{tabular}{llll}
\hline & \multicolumn{3}{c}{ Predicted } \\
\cline { 2 - 4 } Observed & Non- lame & Lame & $\begin{array}{l}\text { Percentage } \\
\text { correct }\end{array}$ \\
\hline Non-lame & 173 & 4 & 97.7 \\
Lame & 13 & 14 & 51.9 \\
Overall percentage & 93.01 & 77.78 & 91.67 \\
\hline
\end{tabular}

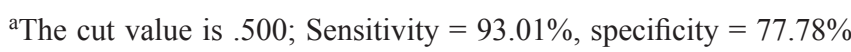
and accuracy $=91.67 \%$.

Results of the model revealed that the explanatory variables like hoof disorders $(\mathrm{OR}=16.98 ; 95 \% \mathrm{CI}=4.67-61.66)$, $\mathrm{BCS}(\mathrm{OR}=6.99 ; 95 \% \mathrm{CI}=1.72-28.37)$ and hock injury $(\mathrm{OR}=11.99 ; 95 \% \mathrm{CI}=3.243-44.337)$ were the significant $(p<0.01)$ predictors of lameness (Table 3$)$. Cows with hoof disorders had seventeen times more chances of becoming lame than those cows having normal hooves. Cows with lower BCS $(<3)$ had seven times more chances than those having $\mathrm{BCS} \geq 3$. Cows with injured hocks had 12 times more chances of becoming lame than those have normal hocks. In the present study, the variables like parity, animal hygiene and foot angle were not the significant $(\mathrm{p}>0.05)$ predictor of lameness (Table 3 ). 
Table 3: Final binary logistic regression model for prediction of lameness in crossbred dairy cattle

Variables in the Equation

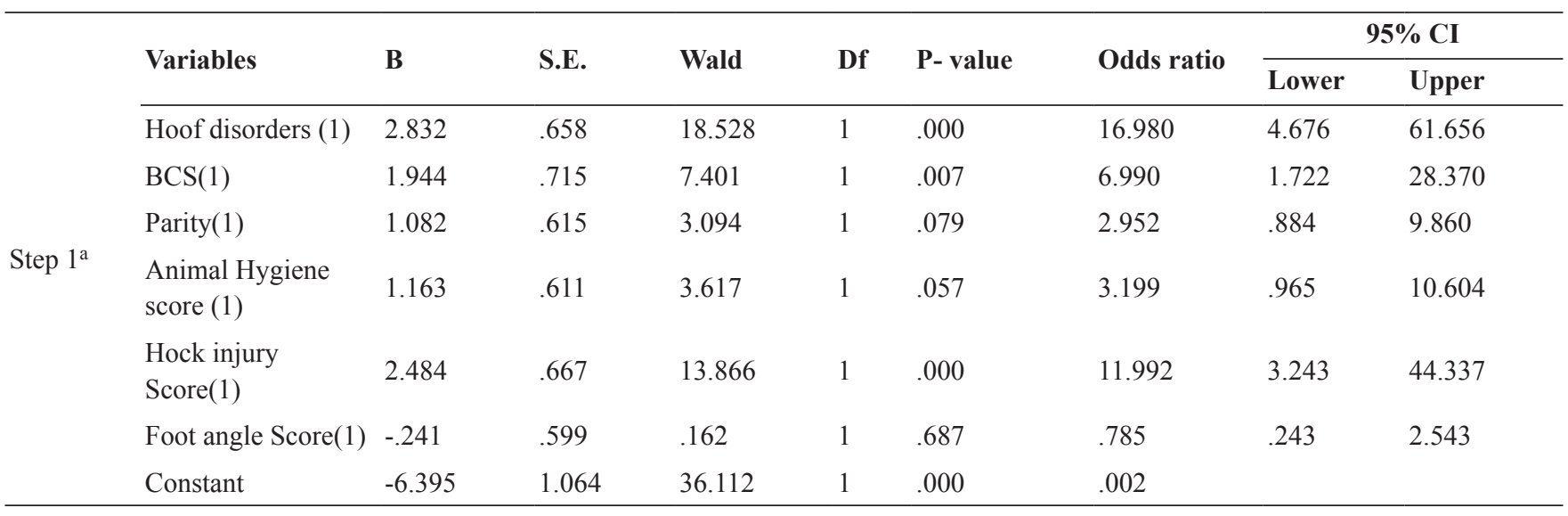

Variable(s) entered on step 1: Hoof Disorder : $1=$ Healthy Hoof, $2=$ Hoof with disorder; BCS: $1=\geq 3,2=<3$; PARITY: $1=\leq 3$ parity, $2=>3$ parity, ANIMAL HYGIENE: 1= clean , 2= dirty; HOCK INJURY SCORE:- $1=$ normal, $2=$ injured; FOOT ANGLE SCORE: $1=$ intermediate, $2=$ Shallow ; P values $<0.05$ are statistically significant.

\section{CONCLUSION}

The recorded incidence estimates indicate that Holstein Friesian crossbred dairy cattle are more prone to lameness than Jersey crossbred dairy cattle. The animal level risk factors like the advancement in age and parity, lower body condition score, hoof disorders, white-coloured hooves, shallow foot angle, injured hocks and knees and animal hygiene had a significant association with lameness. The herd level risk factors like dirty flooring conditions, freestall housing conditions and cemented flooring also had a significant association with lameness. It is concluded that hoof disorders, hock injuries and lower BCS can be used as a significant predictor of lameness in crossbred dairy cattle.

\section{ACKNOWLEDGEMENTS}

The first author is thankful to the ICAR-NDRI for providing financial assistance in terms of institutional fellowship and also thankful to the Farmers FIRST Project, ICARNIANP, Bengaluru for providing funds and Director, ICAR-NDRI, Karnal, Director, ICAR-NIANP, Bengaluru and Head, SRS-ICAR-NDRI, Bengaluru for providing the necessary facilities for carrying out the work.

\section{REFERENCES}

Animal Comfort Tool. On farm feedbunk alley floor cleanliness. 2011. https://www.dairyresearch.ca/pdf/2FFLOOR $\% 20$ CLEANLINESS\%20 BOOT\%20TEST SOP 210311.pdf Accessed 5 August 2017

Bicalho, R.C., Machado, V.S. and Caixeta, L.S. 2009. Lameness in dairy cattle: A debilitating disease or a disease of debilitated cattle? A cross-sectional study of lameness prevalence and thickness of the digital cushion. J. Dairy Sci., 92: 3175-3184.

Bran, J.A., Darosb, R.R., Keyserlingk, M.A.G.V., LeBlancc, S.J. and Hotzela, M.J. 2018. Cow- and herd-level factors associated with lameness in small-scale grazing dairy herds in Brazil. Prev. Vet. Med., 151: 79-86.

Brenninkmeyer, C., Dippel, S., Brinkmann, J., March, S., Winckler, C. and Knierim, U. 2012. Hock lesion epidemiology in cubicle housed dairy cows across two breeds, farming systems and countries. Prev.Vet. Med., 209: 236-245.

Chesterton, R.N., Pfeiffer, D.U., Morris, R.S. and Tanner, C.M. 1989. Environmental and behavioural factors affecting the prevalence of foot lameness in New Zealand dairy herds-A case-control study. New Zeal. Vet. J., 37: 135-142.

Cook, N.B. 2003. Prevalence of lameness among dairy cattle in Wisconsin as a function of housing type and stall surface. $J$. Am. Vet. Med. Assoc., 223: 1324-1328.

Dembele, I., Spink, M., Stehulova, I., Panama, J. and Firla, P. 2006. Factors contributing to the incidence and prevalence 
of lameness on Czech dairy farms. Czech J. Anim Sci., 51: 102-109.

Egger-Danner, C., Nielsen, P., Fiedler, A., Müller, K., Fjeldaas, T., Döpfer, D., Daniel, V., Bergsten, C., Cramer, G., Christen, A.-M., Stock, K. F., Thomas, G., Holzhauer, M., Steiner, A., Clarke, J., Capion, N., Charfeddine, N., Pryce, J.E., Oakes, E., Burgstaller, J., Heringstad, B., Odegard, C. and Kofler, J. 2015. ICAR claw health atlas. First edition. http://www.icar. org/Documents/ICAR_Claw_Health_Atlas.pdf . Accessed 2 August 2017.

Fayed, R.H. 1997. Effect of housing systems on behavior and lameness in dairy cows. Veterinary Medical Journal Giza, 45: 101-110.

Ferguson, J.D., Galligan, D.T. and Thomsen, N. 1994. Principal descriptors of body condition score in Holstein cows. $J$. Dairy Sci., 77: 2695-2703.

Flower, F.C. and Weary. D.M. 2009. Gait assessment in dairy cattle. Animal, 3: 87-95.

Gibbons J., Vasseur, E., Rushen, J. and de Passille, A.M. 2012. A training program to ensure high repeatability of injury of dairy cows. Invited paper to Animal Welfare. 21: 379-388.

Green, L.E., Huxley, J.N., Banks, C. and Green, M.J. 2014. Temporal associations between low body condition, lameness and milk yield in a UK dairy herd. Prev. Vet. Med., 113: 6371.

Horseman, S.V., Roe, E.J., Huxley, J.N., Bell, N.J., Mason, C.S. and Whay, H.R. 2014. The use of in-depth interviews to understand the process of treating lame dairy cows from the farmer's perspective. Animal Welfare, 23: 157-165.

Hosmer, D. W., Lemeshow, S., 2000. Applied Logistic Regression. New York: Wiley.

Kara, N.K., Galic, A. and Koyuncu, M. 2011. Effects of stall type and bedding materials on lameness and hygiene score and effect of lameness on some reproductive problems in dairy cattle. J. Appl. Anim. Res., 39: 334-338.

Lim, P.Y., Huxley, J.N., Willshire, J.A., Green, M.J., Othman A.R. and Kaler, J. 2015. Unravelling the temporal association between lameness and body condition score in dairy cattle using a multistate modeling approach. Prev. Vet. Med., 118: 370-377.

Lohith, J., Kataktalware, M.A., Manjunath, D.R., Adarsha, B.D. and Nagappa, B. 2016a. Effect of leg and feet traits on hoof problems or lameness in crossbred dairy cattle under field conditions. Int. J. Livest. Res., 6: 2277-1964.

Lohith, J., Reddy, A.O., Nagappa, B. and Manjunath, D.R. 2016b. The study of incidence of lameness in relations to claw traits in crossbred dairy cattle under field conditions. Int. J. Livest. Res., 6: 31-36.
Matore, Z., Woods, P. and Kagler, S. 2018. Risk factors and indicators of reduced welfare of grazing dairy cows from selected smallholder dairy farms in midlands province, Zimbabwe. Trop. Anim. Health Pro., 50: 1059-1064.

Moreira, T.F., Nicolino, R.R., de Andrade, L.S., Filho, E.J.F. and de Carvalho, A.U. 2018. Prevalence of lameness and hoof lesions in all year-round grazing cattle in Brazil. Trop. Anim. Health Pro., 50: 1829-1834.

Mostafa, A.S. and Mahran, H.A. 2016. Assessment of welfare and health of dairy cows under different housing and management systems. J. Appl. Vet. Sci., 1: 57-69.

Nash, C.G., Kelton D.F., DeVries, T.J., Vasseur, E., Coe, J., Heyerhoff, J.C., Bouffard, V., Pellerin, D., Rushen, J., de Passille, A.M. and Haley, D.B. 2016. Prevalence of and risk factors for hock and knee injuries on dairy cows in tiestall housing in Canada. J. Dairy Sci., 99: 6494-6506.

Phillips, C.J.C. and Morris, I.D. 2001. The locomotion of dairy cows on flor surfaces with different frictional properties. $J$. Dairy Sci., 8: 623-628.

Randall, L.V., Green, M.J., Chagunda, M.G.G., Mason, C., Archer, S.C., Green, L.E. and Huxley, J.N. 2015. Low body condition predisposes cattle to lameness: An 8-year study of one dairy herd. J. Dairy Sci., 98: 3766-3777.

Relun, A., Lehebel, A., Chesnin, A., Guatteo, R. and Bareille, N. 2013. Association between digital dermatitis lesions and testday milk yield of Holstein cows from 41 French dairy farms. J. Dairy Sci., 96: 2190-2200.

Rowlands, G.J., Russell, A.M. and Williams, L.A. 1985. Effects of stage of lactation, month, age, origin and heart girth on lameness in dairy cattle. Vet. Rec., 117: 576-580.

Rutherford, K.M.D., Langford, F.M., Jack, M.C., Sherwood, L., Lawrence, A.B. and Haskell, M.J. 2009. Lameness prevalence and risk factors in organic and non-organic dairy herds in the United Kingdom. Vet. J., 180: 95-105.

Sadiq, M.B., Ramanoon, S.Z., Mansor, R., Hussain, S.S.S. and Mossadeq, W.M.S. 2017. Prevalence of lameness, claw lesions, and associated risk factors in dairy farms in Selangor, Malaysia. Trop. Anim. Health Pro., 49: 1741-1748.

Schreiner, D.A. and Ruegg, P.L. 2003. Relationship between udder and leg hygiene scores and subclinical mastitis. $J$. Dairy Sci., 86: 3460-3465.

Sharma, A. and Phillips, C.J.C. 2019. Lameness in sheltered cows and its association with cow and shelter attributes. Animals, 9: 360. doi:10.3390/ani9060360

Singh, A., Singh, S., Gupta, D.K. and Bansal, B.K. 2018. Relationship of lameness to body condition score, udder health and milk quality in crossbred dairy cattle. Vet. Arh., 88: 179-190. 
Sogstad, A.M., Fjeldaas, T. and Osteras, O. 2011. Association of claw disorders with claw horn colour in Norwegian red cattle - a cross-sectional study of 2607 cows from 112 herds. Acta. Vet. Scand., 53: 59.

Solano,L., Barkema, W.H., Pajor, E.A., Mason,S.,LeBlanc, J.S., Heyerhoff, Z.C.J., Nash, R.G.C., Haley, B.D., Vasseur, E., Pellerin, D., Rushen, J., Passille, M.A. and Orsel, K. 2015. Prevalence of lameness and associated risk factors in Canadian Holstein- Friesian cows housed in freestall barns. J. Dairy Sci., 98: 6978-6991.

Sprecher, D.J., Hostetler, D.E. and Kaneene, J.B. 1997. A lameness scoring system that uses posture and gait to predict dairy cattle reproductive performance. Theriogenology, 47: 1179-1187.

Thomas, H.J, Remnant, J.G, Bollard, N.J, Burrows, A., Whay, H.R., Bell, N.J, Mason, C. and Huxley, J.N. 2016. Recovery of chronically lame dairy cows following treatment for claw horn lesions: a randomised controlled trial. Vet. Rec., 178: 116.
Tyagi, K., Lathwal, S.S., Sharma, J., Devi, I., Gupta, R., Patbandha, T.K. and Tewari, H. 2017. Lameness in crossbred cows: Its effect on productive and reproductive performance. Indian J. Dairy Sci., 70: 443-446.

Van der Tol, P.P.J., Metz, J.H.M., Noordhuizen-Stassen, E.N., Back, W., Braam, C.R. and Weijs, W.A. 2005. Frictional forces required for unrestrained locomotion in dairy cattle. $J$. Dairy Sci., 88: 615-624.

Whay, H.R. and Shearer, J.K. 2017. The impact of lameness welfare of the dairy cow. Vet. Clin. N. Am-Food A., 33: 153164

Whitaker, D.F., Kelly, J.M. and Smith, E.J. 1983. Incidence of lameness in dairy cows. Vet. Rec., 113: 60-62. 
